\title{
Policing during COVID-19: Another day, another crisis
}

\author{
Konstantinos Papazoglou, ${ }^{*}$ Daniel M. Blumberg, ${ }^{\dagger}$ Mike D. Schlosser, ${ }^{\ddagger}$ and Peter I. Collins $\$$,\#
}

\begin{abstract}
"Another Brick in the Wall" of Police Work
The COVID-19 virus is an unprecedented public health emergency. Although many police departments have adopted some novel activities for their officers to perform during the pandemic, such as reading books to homebound schoolchildren over the Internet (Johnson, 2020), for police officers, the current crisis is pretty much just another day at work. Police officers, like most first responders, are accustomed to performing their duties under the most critical circumstances. These are the heroes who run into schools as active shooters are murdering children, who help evacuate buildings during chemical leaks and bomb threats, and who apprehend violent criminals who would do them harm. Police officers routinely put their lives on the line to serve and protect the members of their community.

Without hesitation, police officers continue to work during the present pandemic. While most people are following physical distancing guidelines and many are able to work from home, public safety professionals are not afforded this luxury. On one hand, the crisis is unlike all others and poses some unique challenges for police officers, which are discussed below. On the other hand, however, current circumstances are reminiscent of obstacles faced by officers during previous crises and during the routine performance of their duties.

All first responders are cognizant of the risk of exposure to infectious diseases (e.g., Jahnke, Poston, Jitnarin, \& Haddock, 2012; Shakespeare-Finch, 2011). It was found that "needlestick injuries occur with considerable frequency in this group of law enforcement professionals, suggesting an increased risk of becoming infected with bloodborne pathogens..." (Lorentz, Hill, \& Samimi, 2000, p. 146). Specifically, research has shown that police officers reported elevated anxiety after contact with "blood and bodily fluids" and that pre-incident training about such exposures had no impact on post-incident anxiety levels (Dunleavy, Taylor, Gow, Cullen, \& Roy, 2012, p. 384). Similar findings were observed from a sample of correctional officers whose job stress increased and job satisfaction decreased as their concern about "contracting an infectious disease on the job increased" (Hartley, Davila, Marquart, \& Mullings, 2013, p. 334).
\end{abstract}

An important consideration to mitigate first responders' fears is the extent to which those exposed are provided adequate and immediate medical attention to assess whether the exposure resulted in any actual contagion. Unfortunately, HIV/AIDS, perhaps the most anxiety-provoking health crisis ever faced by police officers, which was discussed over twenty years ago (Flavin, 1998), is not ameliorated by quick medical assessment following possible exposure. Specifically, the threat of contracting HIV/AIDS lingers for months after possible exposure, since infection is not immediately detectable. This poses tremendous challenges for police officers and their loved ones, especially spouses/romantic partners, since that virus is also transmitted sexually.

Although more immediate than HIV/AIDS, the COVID-19 crisis also creates significant challenges for first responders' families. The COVID-19 pandemic adds yet another layer of stress to this already dangerous and stressful job. Officers continue to contract COVID-19, and the number of officer deaths is rising. As reported on CNN, in the city of New York alone, 29 members of the New York Police Department (NYPD) have died due to COVID-19 (Waldrop, 2020). The graphic reality is that the number of officers' deaths will probably keep increasing over the coming months.

Officers are not only concerned about their health, but also the health of their family members. This creates another challenge for officers who attempt to avoid "bringing" work home with them, since many people exposed to COVID-19 remain asymptomatic. Some of these family members may have pre-existing health issues, are elderly, or are in other high-risk groups vulnerable for contracting the COVID-19 infection. Consequently, officers who are concerned about their possible exposure to the virus during a shift may further isolate themselves (physically and emotionally) from family members to avoid infecting a loved one. This isolation adds to officers' already increased level of distress during this crisis.

The Essential Role of Police Leadership during COVID-19 Against the backdrop of the COVID-19 outbreak, it is essential now, more than ever, that officers have the support of their departments. Chiefs and Sheriffs must let their employees know that they appreciate the work they are doing, that their

Correspondence to: Dr. Konstantinos Papazoglou, Yale School of Medicine, 350 George Street, 2 Floor, Office \#A209, New Haven, CT O6511, USA. E-mail: konstantinos.papazoglou@yale.edu

To cite: Papazoglou, K., Blumberg, D.M., Schlosser, M.D., \& Collins, P.I. (2020). Policing during COVID-19: Another day, another crisis. Journal of Community Safety and Well-Being, 5(2), 39-41. https://doi.org/10.35502/jcswb.130

@ Author(s) 2020. Open Access. This work is distributed under the Creative Commons BY-NC-ND license. For commercial re-use, please contact sales@sgpublishing.ca. gPUBLISHING Published by SG Publishing Inc. CSKA Official publication of the Community Safety Knowledge Alliance. 
courage and dedication are acknowledged, and that they will do everything they can to keep officers as safe as possible in terms of both their physical and mental health. At the same time, law enforcement executives have to recognize the added stress on officers who have been tasked with policing violations of physical distancing regulations and the strain placed on officers arising from the ambiguity of fluctuating policies (e.g., Sisak, 2020).

Agencies have put into place numerous protocols in an effort to prevent officers from contracting COVID-19. These protocols are essential not only for officers' protection from COVID-19, but also for providing them with emotional support. For example, many agencies are adopting policies to limit officers' face-to-face interactions with citizens. If a police matter does not involve a violent crime or other emergencies, departments are now taking reports and handling minor issues over the phone or online. These criteria vary from agency to agency, but examples of minor problems include minor traffic accidents, thefts where there is no suspect, and lost or missing property. When officers do have to respond in person, they are being provided with masks, complying with physical distancing rules, and washing their hands regularly.

That being said, officers still need to balance their safety with their obligation to protect the public they serve. Officers must always respond to domestic disputes, in-progress fights, and other disturbances. As part of their regular duties, officers still have to make arrests, search arrestees, separate those who are fighting, control aggressive and resisting subjects, and so on. Regardless of the dangerousness of the call and the risk of contracting COVID-19, the police will respond to protect those who cannot protect themselves, to help those who cannot help themselves, and to maintain civil peace. What else can we do for these heroes?

Police officers' identities expand beyond that of their profession. They are husbands, wives, mothers, fathers, brothers, and sisters. They are citizens, just like those they serve. They have hobbies, are involved in community activities, and like to enjoy the same things as everyone else. They also have emotions and are susceptible to anxiety, depression, and other mental health conditions.

Although there are numerous obvious stressors for police officers, such as handling dangerous calls and witnessing violence and death, it has been shown consistently that organizational stressors are ranked the highest among working officers (Shane, 2010; Violanti \& Aron, 1995; Violanti et al., 2017). Some of these stressors include the operation of a department, the bureaucracy, relations with coworkers, unfavourable policies, and a lack of recognition for good work. These are especially difficult against the backdrop of being disciplined for negative work performance, other officers not doing their fair share, a lack of supervision, and being treated differently than fellow officers (Shane, 2010; Violanti \& Aron, 1995; Violanti et al., 2017).

However difficult, an essential part of officer wellness is to separate off-duty (family, friends, and leisure activities) from on-duty life (Gilmartin, 2002; Papazoglou \& Blumberg, 2019). Because policing is such a vital part of an officer's identity, many carry this identity with them even when offduty. The job itself interrupts family time, such as working odd shifts and holidays (Kirschman, Kamena, \& Fay, 2014; Papazoglou, 2016).

\section{Recommended Action Plan}

Agencies must prioritize protecting officers' emotional health as much as their physical health. Given that officers frequently complain about the stress coming from within the organization, this is the ideal time for agency leadership to step up and create a positive organizational environment for their officers. The following are some suggestions for police leaders and organizations in general to protect officers' mental and physical health and maintain their well-being:

First and foremost, communicate with officers:

Let them know how much you appreciate their courage during this pandemic

- Ensure consistent communication (physical distancing or virtual meetings)

Check in with them to see how they are

Perform wellness checks

Keep them updated on departmental procedures and changes

Ask your officers what they need from you

Provide information on how officers can seek help if needed, including departmental and outside counselling, as well as peer support groups (virtual meetings) Guide them on how to monitor themselves without fear of judgment regarding stress-related reactions. For instance, if they notice changes in their functioning not noticed before the COVID-19 crisis outbreak (e.g., migraine headaches, sore muscles, disrupted sleep), they should be able to seek help from health professionals

- If possible, given strained staffing needs, provide officers with additional time off (e.g., days off, vacation days) if they experience fatigue or exhaustion and especially for those who appear to be highly concerned and overwhelmed by having to care for a vulnerable person at home or are required to assist in homeschooling their children

Offer additional resources, for example:

What Law Enforcement Personnel Need to Know about Coronavirus Disease 2019 (COVID-19), by Centers for Disease Control and Prevention (CDC) https:// www.cdc.gov/coronavirus/2019-ncov/community/ guidance-law-enforcement.html

- Law Enforcement Information on COVID-19, by the International Association of Chiefs of Police (IACP) https://www.theiacp.org/resources/document/ law-enforcement-information-on-covid-19?utm source=Informz\&utm_medium =email\&utm_ campaign=Informz+Email

- Confidential support - Bulletproof https://www. bulletproof.org/

Confidential support-Copline https://copline.org/

- Confidential support - National Suicide Prevention Lifeline https://suicidepreventionlifeline.org/

In conclusion, these are novel times due to a novel virus. Viruses change quickly as they acquire genetic variations. Law enforcement, as well, has to change quickly to adapt to these unusual times. It is therefore paramount that we continue to protect officers psychologically, in addition to protecting them physically. 


\section{CONFLICT OF INTEREST DISCLOSURES}

The authors have no conflicts of interest to declare.

\section{AUTHOR AFFILIATIONS}

*Yale School of Medicine, New Haven, CT, USA; ${ }^{\dagger}$ Alliant International University, California School of Professional Psychology,

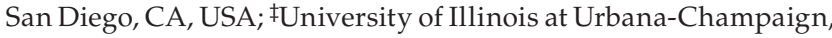
Police Training Institute, Champaign, IL, USA; \$University of Toronto, Division of Forensic Psychiatry, Toronto, ON, Canada; \#Ontario Provincial Police, Criminal Behaviour Analysis Section, Orillia, ON, Canada.

\section{REFERENCES}

Dunleavy, K., Taylor, A., Gow, J., Cullen, B., \& Roy, K. (2012). Police officer anxiety after occupational blood and body fluid exposure. Oc cupational Medicine, 62151, 382-384. https://doi.org/10.1093/ occmed/kgs078

Flavin, J. (1998). Police and HIV/AIDS: The risk, the reality, the response. American Journal of Criminal Justice, 23(1), 33-58. https://doi. org/10.1007/BF02887283

Gilmartin, K. M. (2002). Emotional survival for law enforcement. Tucson, $A Z: E S$.

Hartley, D. J., Davila, M. A., Marquart, J. W., \& Mullings, J. L. (2013). Fear is a disease: The impact of fear and exposure to infectious disease on correctional officer job stress and satisfaction. American Journal of Criminal Justice, 38(2), 323-340. https://doi.org/10.1007/ s12103-012-9175-1

Jahnke, S. A., Poston, W. S. C., Jitnarin, N., \& Haddock, C. K. (2012). Health concerns of the US Fire Service: Perspectives from the firehouse. American Journal of Health Promotion, 2721, 111-118. https://doi. org/10.4278/ajhp.110311-QUAL-109

Johnson, J. R. (2020, April 2). Police doing more than "policing" during COVID-19 crisis Corning Observer (CA).
Kirschman, E., Kamena, M., \& Fay, J. (2014). Working with police families. In Counseling cops: what clinicians need to know (pp. 169-229). New York, London: Guilford Press.

Lorentz, J., Hill, L., \& Samimi, B. (2000). Occupational needlestick injuries in a metropolitan police force. American Journal of Preventive Medicine, 18(2), 146-150. https://doi.org/10.1016/S0749-3797/99|00137-3

Papazoglou, K. (2016). Managing effective transitions: presenting the different shades of police life and the pivotal role of mental health care providers in promoting officers' wellbeing. International Journal of Medical and Health Sciences, 5(3), 121-122. https:// www.ijmhs.net/journals-aid-331.html

Papazoglou, K., \& Blumberg, D. M. (2019). POWER: police officers wellness, ethics, and resilience. San Diego, CA: Elsevier - Academic Press.

Shakespeare-Finch, J. (2011). Primary and secondary trauma in emergency personnel. Traumatology, 17(4), 1-2. https://doi. org/10.1177/1534765611431834

Shane, J. M. (2010). Organizational stressors and police performance. Journal of Criminal Justice, 38(4), 807-818.

Sisak, M. R. (2020, May 3). "Not acceptable": Violent arrest raises concerns about NYPD distancing patrols amid coronavirus pandemic. USA Today. Retrieved from: https://www.usatoday.com/story/ news/nation/2020/05/03/coronavirus-nypd-distancing-patrolsarrest-donni-wright/3076121001/

Violanti, J. M., \& Aron, F. (1995). Police stressors: Variations in perception among police personnel. Journal of Criminal Justice, 23(3), 287-294.

Violanti, J. M., Charles, L. E., McCanlies, E., Hartley, T. A., Baughman, P., Andrew, M. E., ... Burchfiel, C. M. (2017). Police stressors and health: a state-of-the-art review. Policing: An International Journal of Police Strategies \& Management, 40(4), 642-656.

Waldrop, T. (2020, April 19). New York City police department has lost 29 members to COVID-19. CNN. Retrieved from: https://www. cnn.com/2020/04/19/us/new-york-city-police-covid-19-deaths/ index.html 